\title{
EFFECT OF MIRROR THERAPY ON UNILATERAL SPATIAL NEGLECT IN STROKE PATIENTS
}

\author{
Sholeh Nurul Hidayat'1), Hendri Kurniawan²) \\ 1)Occupational Therapy Unit, Medical Rehabilitation, \\ Dr. Kariadi Hospital Semarang \\ 2) Department of Occupational Therapy, Health Polytechnics, \\ Ministry of Health Surakarta
}

\begin{abstract}
Background: Stroke can cause unilateral spatial neglect (USN), a disturbance in orientation and response to stimuli on the side of the body that is different from the location of the lesion in the brain. Mirror therapy is proven to improve the motor skills of stroke patients through visual feedback stimulation to trigger motion planning on the affected side of the body. This study aimed to determine the effect of mirror therapy on unilateral spatial neglect of stroke patients.

Subjects and Method: This was a quasi-experiment study with pre and post-test one group design, conducted at 3 hospitals in Semarang, Central Java, from October to November 2019. A total of 19 stroke patients was selected by purposive sampling. The dependent variable was unilateral spatial neglect. The independent variable was mirror therapy. The data were collected by Catherine Bergego Scale (CBS) instruments and analyzed by paired t-test.

Results: CBS score after intervention (Mean $=13.84$; $\mathrm{SD}=6.36)$ was lower than before intervention (Mean=21.32; $\mathrm{SD}=5.89)$ and it was statistically significant $(\mathrm{p}<0.001)$

Conclusion: Mirror therapy is effective in lowering unilateral spatial neglect scores among patients with stroke.

Keywords: mirror therapy, spatial neglect, stroke

\section{Correspondence:}

Sholeh Nurul Hidayat. Occupational Therapy Unit, Medical Rehabilitation, Dr. Kariadi Hospital Semarang. Jl. DR. Sutomo 16, Semarang, Central Java, Indonesia. Email: sholehruby38@gmail.com. Mobile: +6285728843163
\end{abstract}

